\title{
Intersectionality as embodiment
}

By Sune Qvotrup Jensen aNd CAMIlla Elg

The debates about intersectionality bave been running for a number of years. Experience has been part of the debates, but the embodied dimension of experience tends to be forgotten. How can the inclusion of embodied experience be fruitful for an intersectional analysis?

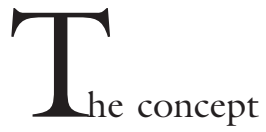

intersectionality has been employed since Crenshaw introduced it in 1989. In perhaps the most influential of the early articles dealing with intersectionality she writes about domestic violence towards women of colour (Crenshaw 1991). She explains that because of the intersections between class matters (unemployment, poverty, etc.),


vices) and gender matters (heterosexual partnerships, motherhood, etc.) these women have specific experiences (Crenshaw 1991) shaped by the ways the different differentiations intersect. Importantly these women share the experience of having their bodily integrity violated through domestic violence.

Meyers emphasizes, in line with Crenshaw, the centrality of experience in intersectional thinking when she notes that: "The idea of intersectional identity is premised on the general philosophical thesis that who one is depends on one's social 
experience" (2000: 153). In other words, the relational and social formation of intersectional identity takes place through a wide range of social experiences and these experiences differ in ways, which are related to gender, class, ethnicity, and race etc. (Phoenix and Pattynama 2006).

We aim in this article to relocate the discussion about intersectionality and suggest a perspective on embodied experience as a means of broadening studies of the individual as intersectional as well as researching the power relations that affect the social construction of individuals. We are inspired by the corporeal turn in sociology and visual sociology (Taussig 1993, Buck-Morss 1994, Crossley 1995, Skeggs 1997, Sampson 1998, Witz 2000, Bourdieu 2000, Entwistle 2000, Gebauer and Wulf 2001, Wacquant 2004, Young 2005, Shilling 2007, Bacchi and Beasley 2007). These inspirations enable us to reconsider the relation between individuality and embodiment and to sketch out our perspective on embodied experience. We consider this perspective an important alternative to the current focus on discursive identity construction although it does not exclude the importance of discourses.

Embodiment and intersectionality are complex concepts and approaches, which we necessarily have to address in a simplified manner given the limits of this article. We use the concept of embodiment to denote the processes through which the social is incarnated in human beings, whereas we consider intersectionality a conceptual metaphor for the mutually constitutive interplay and interwovenness between different forms of social differentiation.

Our discussion raises two aspects. The first is the question of experience. As mentioned, notions of experience have implicitly been part of intersectionality debates. We wish to strengthen an embodiment perspective in the discussion about experience as this has largely been absent in intersectionality debates. Secondly, the debate about structure versus agency has found a new home in the discussions about intersectionality. We find that strengthening the embodiment perspective could enable a rethinking of the binary figure of structure vs. agency.

\section{INSPIRATION FROM PHENOMENOLOGY}

The inspirations we draw upon are directly or indirectly related to Merleau-Ponty's phenomenological understanding of subjectivity as embodied (Merleau-Ponty 1963, Dauer-Keller 2001). Young sums up the achievements of Merleau-Ponty for contemporary thinking in the following way:

Within the phenomenological tradition, Merleau-Ponty took the revolutionary step of theorizing consciousness itself as embodied. The subject who constitutes a world is always an embodied subject. [...] There is no situation $[\ldots]$ without embodied location and interaction. Conversely, the body as lived is always layered with social and historical meaning and is not some primitive matter prior to or underlying economic and political relations or cultural meanings (Young 2005: 9).

However, she notes, the critiques in recent French philosophy inspire scepticism of Merleau-Ponty's concept of consciousness, which "assumes the subject as unitary and original to experience" (Young 2005: 9). Furthermore she suggests that we leave the expectation behind, detected in some of Merleau-Ponty's writing, of a "pure embodied experience" prior to social conditioning and structural positioning (ibid). Young maintains, however, that the inspiration from Merleau-Ponty is still fruitful.

This is not least the case for our understanding of intersectional individuality. It inspires us to scrutinize whether analyses of narratives and discourses tell us enough about intersectionality 'at work'. As the subject is "always an embodied subject" 
(ibid) and as embodiment is necessarily shaped by its material and social conditions, as we will explain below, this formation is radical, in that it not only affects material and sensational aspects of embodiment, but also the thoughts and the consciousness intertwined herein. This embodied individual experience is what Merleau-Ponty calls "the phenomenological world":

The phenomenological world is not pure being, but the sense which is revealed where the paths of my various experiences intersect, and also where my own and other people's intersect and engage each other like gears. It is thus inseparable from subjectivity and intersubjectivity, which find their unity when I either take up my past experiences in those of the present, or other peoples in my own (Merleau-Ponty 1963: xviii).

It is important to note the deeply relational nature of experience Merleau-Ponty describes here. He states that the world as we experience it - "the phenomenological world" - is what is happening where different experiences - ours as well as others engage each others like gears. The claim is that while embodiment is material in the middle of materiality, it is also perception shaped by the perceived; it is relational and deeply situated (Crossley 1995: 48). In relation to our focus on social positioning as a situated, embodied process, we find Merleau-Ponty's idea that other people's experiences engage in our 'own' striking.

It follows from Merleau-Ponty that because different social differences are embodied in the same embodiment, it is necessarily intersectional. As lived embodied experience social differences are always intersectional. Intersections of gender, class, ethnicity, race, sexuality, etc. affect what we experience as it is woven into our perceptions, into how we are perceived by others, how others treat us, how others' experiences engage in ours, where and how we live, what we do, how empowered we are, which groups we participate in, how 'natural' our surroundings seem, etc.

Phenomenological thinking of embodiment has been criticized by feminist scholars for being gender biased (Cawood and Juelskjær 2005, Young 2005, Moi 2005). Cawood and Juelskjær criticize MerleauPonty's phenomenology for "speaking of a concrete ideal of the body, masked as the body in general" (Cawood and Juelskjær 2005: 20). The critique finds Merleau-Ponty to be speaking of the body in terms that are too general, and to be forgetting that embodiment is radically differentiated. While we recognize this tendency in some of Merleau-Ponty's writing, we find that with inspiration from Merleau-Ponty's understanding of experience as embodied, we can explain how gender and other social differences are embodied. The radicality of the phenomenology of embodiment is therefore not antithetical to an analytical sensitivity to gender.

Cawood and Juelskjær, furthermore, argue that the phenomenological understanding of an embodied individual, which reaches out into the world in an unrestricted way is based on an understanding of male bodies. However, to us the "unrestrictedness" (Cawood and Juelskjær 2005: 20) of embodied participation is not the central insight of Merleau-Ponty's phenomenology. If perception of the world is shaped by "various experiences" (MerleauPonty 1963, cited above) - our own as well as others' - our 'reach out' will always be restricted by the horizon of all these experiences. As we reach out and act in the physical world we are also being exposed to and shaped by social differentiations and power structures.

It is precisely this feature of the body, the quality of being and having to be exposed and open to the world, which necessarily creates differentiated embodiment. In other words to the extent the body is not gendered, classed, racialized, etc. in prior phenomenological thinking this is 
not due to problems in the basic premises of this thinking per se, but due to these premises not being driven to their consequences in this respect. Moi makes an attempt at this when she reads Merleau-Ponty's formulations about embodied perceptions as the background for all agency up against Beauvoir's thoughts on the female body as the gendered background for the agency of women (2005: 91-93). Moi quotes Merleau-Ponty's foreword to Phenomenology of perception where he claims that: "The world is not an object such that I have in my possession the law of its making; it is the natural setting of, and the field, for all my thoughts and all my explicit perceptions" (Merleau-Ponty 1963: x-xi, cited from Moi 2005: 195). This underlines our perceptions as being radically conditioned by our world, while it, as Moi points out, also outlines the body as "what we are" as well as "the medium through which we are to have a world" (2005: 195). In her reading of Merleau-Ponty Moi writes: "To consider the body as a background is to allow that its importance for our projects and sense of identity is variable" (2005: 196). She thus sees the possibilities of grasping differing identity and agency experiences within MerleauPonty's thinking. However, drawing upon Beauvoir, Moi argues that Merleau-Ponty does not take into account that in a patriarchal society, women to a much higher degree than men have to understand themselves as gendered bodies (2005: 196). From an intersectionality perspective it can similarly be argued that Western colonial thought has understood black men as mindless bodies (Mercer and Julien 1988). One main point of thinking intersectionality as embodiment is then to break with the idea that some groups or individuals are more embodied than others. This idea prevails in contemporary white masculine thought, which has a tendency to consider other groups than white men in terms of the body - and white men in terms of ra- tionality and the mind (Schott 2004). However, to work with intersectionality means to include the majority in the analytical object (Staunæs 2004). Here we insist, with Merleau-Ponty, that there can be no social life without embodied exposure to the world, and therefore the social life of all human beings has an embodied dimension.

To us Merleau-Ponty, furthermore, inspires an understanding of experience as embodied beyond cognitive and discursive productions of meaning. In our understanding experience can have an embodied dimension, which comes from being in touch with the world, sensing it, and not necessarily decoding it in ways that rely upon discursive repertories. Consequently in our understanding of experience we differ from authors who have criticized the concept of experience from a discursive point of departure. Scott, for instance, criticized feminist standpoint theory, which claimed that engagement with women's experiences is a prerequisite for an adequate understanding of gender $(1991,1992)$. As McNay has noted, standpoint feminism's notion of experience is problematic because the idea that taking women's experience as a direct path to valid knowledge of gender represents something dangerously close to empiricism (2004: $178 \mathrm{ff}$ ). Against the epistemological problems of standpoint feminism, Scott argued that experience is always discursive, because it is interpreted through discursive repertoires (Scott 1991, 1992).

The epistemological problems pointed out by Scott persist in the theoretical history of the intersectionality concept for instance when Collins argued that thinking intersectionally corresponds with the way black women experience the world (1990). This 'theoretical primacy' of black women as the intersectional subject par excellence has been criticized by Gans (2008).

We consider Scott's critique valid in the sense that women's narratives about experi- 
ences of gender are neither unaffected by discursive repertoires, nor offer a privileged entrance point to understanding gender. However we want to argue for the possibility of a non-cognitive and radically embodied understanding of experience as something that forms all subjects (i.e. not just women or black women).

Summing up, Merleau-Ponty offers arguments that the social life of all human beings has an embodied dimension and that there are bodily dimensions of experience, which do not have to be discursively mediated as they do not work on the basis of representations, symbols, or signs.

\section{THE MIMETIC FACULTY}

The complexities of embodied experience can be explored further by addressing the mimetic faculty. Early in the century developmental psychologists researched this faculty in order to understand the socialization of children (Gebauer and Wulf 2001) and Benjamin (1936/1994) wrote about it in relation to sensory and aesthetic experiences and the perception of media (Elg 2009).

Benjamin describes the mimetic faculty as a capacity to "become other" (1936/ 1994). Mimesis is then a name for the impulse to embody what we are sensing as a result of a spontaneous creativity (Elg 2009: 33). This takes shape as an ability to imitate what we sense. The ability to imitate - and to 'overtake' and reproduce the imitation as embodiment - is crucial for the reproduction of practices and for learning (Bourdieu 2000: 134). Furthermore, the mimetic faculty provides an ability and a predisposition to spontaneously empathize with other beings and their emotions (Bråten 1998). It therefore produces a sensed connection to the bodies of other beings. Imitating and empathizing are closely intertwined as it is through imitation between bodies that affective connection is produced. Socially spontaneous mimicking and empathizing are thus crucial for how relations unfold and for how the individual will be constructed in concrete situations (Elg 2009).

Pierre Bourdieu has built his theory of habitus upon these ideas, and he claims there is a biological, neurological dimension of this mimetic faculty (2000: 134). He describes the embodied engagement in the world as effecting a "durable transformation of the body":

... to speak of dispositions is simply to take note of a natural disposition of human bodies [...] a conditionability in the sense of a natural capacity to acquire non-natural, arbitrary capacities. To deny the existence of acquired dispositions is to deny the existence of learning in the sense of a selective, durable transformation of the body through the reinforcement or weakening of synaptic connections (Bourdieu 2000:136, emphasis in original).

This also means that the embodied individual is continuously exposed to social structures. McNay points out: "The habitus is in a state of permanent revision, but this revision is rarely radical because the new and unexpected is always incorporated upon the basis of previously established, embodied dispositions" (2001: 151). In this sense our thinking runs contrary to, for example, Giddens' idea of the body as part of a reflexive project of the self, altered by the individual in accordance to his or hers preferences (Giddens 1991). To us, the embodied individual has agency, but it is impossible to choose not to be exposed to social relations or not to be conditioned by one's experiences (Bourdieu 2000:142). This, of course, implies openness towards power structures as well.

The embodied being is always individual and personal as well as collective. Thus, Bourdieu maintains that the body "indisputably functions as a principle of individuation" (Bourdieu 2000: 133). The body inhabits a specific point in space (socially and 
physically) and it can, beyond infancy, continue living without symbiosis with other bodies. However the body is also a "principle of "collectivization"' (ibid.) since it is literally a product of collective existence and formed by its social and material environment, which is shared with others.

Thus, the mimetic ability to be constructed by its environment provides the individual with dispositions for agency that are in tune with the worlds in which it acts. Bourdieu points to a very important aspect of this intimate relation between the embodied being and the world when he insists that this agency to a large extent is not achieved through a cognitive decoding of signs in the surroundings. As we are conditioned we are also "oriented towards the world" (Bourdieu 2000: 142) and able to provide an "adequate response, having a hold on it, using it (and not decoding it) as an instrument well at hand" (ibid.).

Summing up, the concept of the mimetic faculty offers an understanding of how the social is embodied through mimetic relations with other beings.

\section{Challenging Butler}

Due to its thematic familiarity we find it relevant here to consider Butler's influential work on the body as discursively constructed (Butler 1993). The theory of embodiment we have outlined implies that a focus on discourses will not entail the whole spectre of the social construction of the human individual (Elg 2009). Hence from this perspective Butler treats the material and sensational qualities of the body too lightly (Lykke 2008: 83, Bacchi and Beasley 2007, Sampson 1998, Young 2005, Witz 2000, Hughes and Witz 1997). Approaching the intersectional individual as embodiment implies at least two claims that come to terms with Butler. One problem, often detectable in Butler-inspired understandings of the body, is that her discursive approach tends to treat the body as a surface, with social meanings appearing as bodily signs on it to be read (for instance Staunæs and Søndergaard 2006: 46, 50). In the words of Witz the body appears in Butler's writings as a "surface given meaning through discourse" (2000:8). This is problematic because the body then appears open for inscription, but is not itself active in the process of socialization. However, with Merleau-Ponty's phenomenology and the concept of mimesis we argue that the body is a site for action and not "raw material” (Lykke 2008: 99) for the inscription of social meaning.

To illustrate these processes further we can employ Hasse's concept of sprezzatura (2002), which denotes how a sense of what is appropriate is embodied in a mimetic relation to others. Her study analyses how appropriate ways of being a physics student are learned in collective non-discursive processes, which rely largely on bodily gestures such as gazes and facial expressions.

Similar processes can be said to be at work when we learn, for instance, appropriate gender identity. The point is that, as McNay notes: "The acquisition of gender identity does not pass through consciousness $[. .$.$] bodily dispositions are [. .$.$] lived$ as a form of "practical mimesis" (1999: 101). For instance Crossley points out that: "Women talk differently from men" (2007: $85)$. In an intersectionality perspective we should of course add that ways of speaking also depend on class and race or ethnicity. However, we find it fruitful to maintain that such differentiated ways of talking are learned in mimetic processes that the body actively seeks to engage in.

A second, but related, problem in Butler's approach is the understanding of the mimetic faculty implied in her critique of Bourdieu: "For Bourdieu, practical mimeticism for the most part works, and this achieved congruence between field and habitus establishes the ideal of adaption as the presiding norm of his theory of sociality" (Butler 1999: 118). 
Butler reads the "practical mimeticism" in the work of Bourdieu as an ideal of adaption; a normative aspect of Bourdieu's theory rather than valid sociological observation. To us pointing to adaption is an observation, not the articulation of an ideal. In fact Bourdieu is fully aware that adaption also serves as a vehicle of domination (2000). Therefore we find Butler's critique of this observation normatively puzzling. The critique can be related to a tendency in Butler-inspired social constructionism: While it mentions the reality of structural or collective formation of individuality it has a tendency to consider it an ideological, normative obstacle that should be overcome (Prins 2006). This tendency could also be called normative, as it takes shape as an ideal of liberation from adaption. As we have shown above, we do not find that adaptations such as acquired dispositions are added to the individual in a way that makes it possible to be liberated from them. From our point of view the "durable transformation" (Bourdieu 2000: 136) is a basic feature of human embodiment, which is a necessary, although powerful, dimension of engagement in social relations.

\section{RETHINKING STRUCTURE AND AGENCY}

As mentioned in the introduction the debate about structure and agency has found a new home in the intersectionality discussion. For instance Prins (2006) divides intersectional thought into systemic and constructionist approaches (Phoenix 2006). According to Prins, the systemic approaches take individuals "to be the passive bearers of the meanings of social categories" (2006: 280). That could be rephrased as being positioned within pre-defined categories that you have no possibility of actively influencing. In contrast Prins describes the constructionist understanding of intersectionality as implying "that the individual is $[\ldots]$ made into a source of his or her own thinking and acting" (2006: 280).
It seems that Prins' categorization is in fact an euphemized way of speaking of structure and agency. It is then an example of the structure vs. agency division being rearticulated within the intersectionality debate. From an embodiment perspective this division is problematic, as it can be argued that the distinction is maintained, because the complex character of embodied experience is not taken into account. Putting embodied experience into the equation offers a way to rethink this division, because the body is never fully individual or fully collective, and because embodiment is at the same time socially conditioned and a site of agency.

As argued above, embodiment is always structured as it works through experiencing conditions of life shaped by gender, class, ethnicity, race, etc. However, embodiment at the same time provides the individual with agency. Through mimesis the individual achieves practical knowledge about how to do things like use tools, dance, or socialize at a dinner party. The continued practical engagement in the world accumulates a practical sense. That is, through engagement with the world a repertoire for action, and a sense of which actions are relevant in which contexts is continuously created as embodiment. Therefore, embodiment generates a practical rationality, which does not rely on analytical conceptualization. The responsiveness inherent in this practical rationality should be recognized as agency.

An illustration of embodiment as a site of agency is found in Dreyfuss and Dreyfuss' phenomenology of human learning (Flyvbjerg 2001). According to Dreyfuss and Dreyfuss human learning does not consist of learning to reflexively apply context-independent rules. Analytical problem solving is only one specific type of human action. On the contrary Dreyfuss and Dreyfuss maintain that human action at the expert level is intuitive, holistic and embodied. It "comes primarily from the experi- 
ences on one's own body and is in this way at one with the performer" (Flyvbjerg 2001: 18-19). Dreyfuss and Dreyfuss provide the example of experienced paramedics performing more adequate treatment to persons with acute heart failure compared to trainees learning to give first aid. Despite not remembering, or perhaps never have been introduced to, the formal rules of first aid from which the trainees act, the experienced paramedics provide the most adequate treatment, because their experience provides them with an embodied, intuitive sense of the relevant actions (Flyvbjerg 2001: 10).

The overall point is that it is the exact same processes of socialization by which we learn capacity for agency that condition us in a powerful ways. As a consequence of the perspective on embodied experience we have outlined above, it is therefore possible to argue that structure and agency are not different empirical phenomena, but different dimensions of the same phenomena. With embodiment as point of departure, any focus on agency and not structure must then be seen as strictly analytical. Embodied being will always be both.

\section{CONCLUSION}

In this article we have outlined an understanding of the socially constructed individual as intersectionally embodied. This embodiment is open to the world and it has an impulse as well as a need to engage in the world; to socialize. For this reason embodiment is also socially conditioned. With the mimetic faculty it is formed by this engagement. Furthermore, it accumulates capacity for action and agency by this engagement. Another way to say this is that the individual is formed by the experiences the embodied being has throughout its life as it is engaged in the social world by necessity. These experiences are shaped by gender, class, ethnicity, race, etc. since our intersectional positioning to a very high degree af- fects how we are perceived by others, how others treat us, how 'natural' we are perceived to be by our surroundings, etc. In this sense intersectionality works as embodiment.

\section{Note}

1. We use the category 'race' with reluctance, since the human, social differentiations grasped by this concept will never be, strictly speaking, racial. However, since race is the name of social differentiations in society as we know it, it is a term social science cannot do without.

\section{LITERATURE}

- Bacchi, Carol and Beasley, Chris (2007): "Envisaging a new politics for an ethical future. Beyond trust, care and generosity - towards and ethic of 'social flesh'", in: Feminist theory 2007/3.

- Benjamin, Walther (1936/1994): "Kunstværket i dets tekniske reproducerbarheds tidsalder", in: Kultur og Klasse 1994/1.

- Bourdieu, Pierre (2000): Pascalian Meditations. Polity Press, Cambridge.

- Bråten, Stein (1998): Kommunikasjon og samspill. Fra fødsel til alderdom. Tano Aschehough, Oslo.

- Buck-Morss, Susan (1994): ”Æstetik og anæstetik. Walther Benjamins 'kunstværksessay' revurderet", in: Kultur og klasse 1994/1.

- Butler, Judith (1993): Bodies that matter. On the discursive limits of "sex". Routledge, London.

- Butler, Judith (1999): "Performativity's Social Magic”, in: Richard Schusterman (ed.): Bourdieu. A critical reader, Sage, London

- Cawood, Sarah Højgaard and Juelskjær, Malou (2005): "Kropslig subjektivering", in: Kvinder, Køn \& Forskning 2005/3.

- Collins, Patricia Hill (1990): Black Feminist Thought: Knowledge, Consciousness, and the Politics of Empowerment. Unwin Hyman, Boston.

. Crenshaw, Kimberle W. (1989): "Demarginalizing the Intersection of Race and Sex: A Black Feminist Critique of Antidiscrimination Doctrine, Feminist Theory and Antiracist Politics", in: University of Chicago Legal Forum 1989.

. Crenshaw, Kimberle W. (1991): “Mapping the Margins - Intersectionality, Identity Politics and 
Violence Against Women of Colour", in: Stanford Law Review 1991/6.

. Crossley, Nick (1995): "Merleau-Ponty, the Elusive Body and Carnal Sociology", in: Body and Society 1995/1.

. Crossley, Nick (2007): "Researching embodiment by way of 'body techniques", in: Chris Shilling (ed.): Embodying Sociology. Retrospect, progress and prospects. Blackwell, Oxford.

. Dauer-Keller, Kurt (2001): "Intentionality in perspectival structure", in: Chiasmi International: Trilingual studies Concerning Merleau-Ponty's Thoughts.

· Elg, Camilla (2009): "At være er at være set - et visuelt perspektiv på sociale positioner", in: Kvinder, Kon and Forskning 2009/1.

- Entwistle, Joanne (2000): The Fashioned BodyFashion, Dress and Modern Social Theory. Polity Press, Cambridge.

- Flyvbjerg, Bent (2001): Making Social Science Matter. Cambridge University Press, Cambridge.

- Gans, Jennifer C. (2008): "Re-thinking intersectionality", in: Feminist Review 2008/1.

- Gebauer, Gunter and Wulf, Christoph (2001):

Kroppens sprog. Gyldendal, København.

- Giddens, Anthony (1991): Modernity and selfidentity. Polity Press, Cambridge.

- Hasse, Cathrine (2002): Kultur i bevagelse: fra deltagerobservation til kulturanalyse - $i$ det fysiske rum. Samfundslitteratur, Frederiksberg.

- Hughes, Alex and Witz, Anne (1997): "Feminism and the Matter of Bodies: From de Beauvoir to Butler", in: Body and Society 1997/1.

- Lykke, Nina (2008): Kønsforskning. Forlaget Samfundslitteratur, Frederiksberg.

- McNay, Lois (1999): "Gender, Habitus and the Field", in: Theory, Culture and Society 1999/1.

- McNay, Lois (2001): "Meditations on Pascalian Meditation", in: Economy and Society 2001/1.

- McNay, Lois (2004): "Agency and experience: Gender as a lived relation”, in: Lisa Adkins and Beverly Skeggs (eds.): Feminism after Bourdieu. Blackwell, Oxford.

- Mercer, Kobena and Julien, Isaac (1988): "Race, Sexual Politics and Black Masculinity: A Dossier", in: Rowena Chapman, and Jonathan Rutherford (eds.): Male order: Unwrapping masculinity. Lawrence and Wishart, London.

- Merleau-Ponty, Maurice (1963): Phenomenology of Perception. Routledge, London.

- Meyers, Diana Tietjens (2000): "Intersectional identity and the authentic self? Opposites Attract", in: Catriona Mackenzie and Natalie Stoljar (eds.):

Relational Autonomy. Oxford University Press, Oxford.
- Moi, Toril (2005): Sex, Gender and the Body. Oxford University Press, Oxford.

- Phoenix, Ann and Pattynama, Pamela (2006):

"Intersectionality", in: European Journal of

Women's Studies 2006/3.

. Phoenix, Ann (2006): "Interrogating intersectionality: Productive ways of theorising multiple positioning”, in: Kvinder, Køn \& Forskning 2006/2-3.

- Prins, Baukje (2006): "Narrative Accounts of Origins: A Blind Spot in the Intersectional Approach?", in: European Journal of Women's Studies 2006/3.

- Sampson, Edward (1998): "Life as an Embodied Art: The Second Stage - Beyond Constructionism", in: Betty Bayer and John Shotter (eds.): Reconstructing the Psychological Subject. Bodies, Practices, and Technologies. Sage, London.

- Schott, Robin May (2004): Feministisk filosofi.

Gyldendal, København.

- Scott, Joan (1991): "The Evidence of Experience", in: Critical Inquiry 1991/4.

- Scott, Joan (1992): "Experience", in: Judith Butler and Joan Scott (eds.): Feminists theorize the political. Routledge, London.

- Shilling, Chris ed. (2007): Embodying Sociology. Retrospect, progress and prospects. Blackwell, Oxford.

- Skeggs, Beverly (1997): Formations of class and gender. Becoming respectable. Sage, London.

- Staunæs, Dorthe and Søndergaard, Dorte Marie (2006): "Intersektionalitet - udsat for teoretisk justering”, in: Kvinder, Køn \& Forskning 2006/2-3.

- Staunæs, Dorthe (2004): Køn, etnicitet og skoleliv. Forlaget Samfundslitteratur, Frederiksberg.

- Taussig, Michael (1993): Mimesis and alterity. A particular History of the Senses. Routledge, London.

- Wacquant, Löic (2004): Body and soul. Oxford University Press, New York.

. Witz, Anne (2000): "Whose Body Matters? Feminist Sociology and the Corporeal Turn in Sociology and Feminism", in: Body and Society 2000/2. - Young, Iris Marion (2005): On Female Body Experience: "Throwing Like a Girl" and Other Essays. Oxford University Press, Oxford. 


\section{SUMMARY}

Intersectionality as embodiment.

This article explores intersectionality as embodiment, arguing that by taking embodiment into account broader possibilities of intersectional analysis can be unfolded. Inspired by phenomenological theories of embodied experience and the mimetic faculty, the article suggests that intersectionality can be understood as embodied experience. Following this thinking embodiment is radically conditioned as well as a site of agency. This has implications for the understanding of structures, agency as well as their interrelation.

Sune Qvotrup Jensen, Assistant Professor Department of Sociology, Social Work and Organisation Aalborg University.

Camilla Elg, Post.doc.

Department of History, International and Social Studies

Aalborg University. 